\title{
PENGARUH KEPEMIMPINAN DAN KAPABILITAS DINAMIS TERHADAP MANAJEMEN PENGETAHUAN DI BINUS UNIVERSITY JAKARTA
}

\author{
Teguh Sriwidadi \\ Management Department, School of Business Management, Binus University \\ Jln. K.H. Syahdan No. 9, Palmerah, Jakarta Barat 11480 \\ teguhfemale@gmail.com
}

\begin{abstract}
This research aims to analyze the effect of Leadership and Dynamic Capabilities on Knowledge Management at BINUS University. Research objects are lecturers and employees of BINUS Unversity with 90 respondents. Sampling technique used is disporporsiaonte stratified random sampling procedure, the number of subjects of each stratum would no be altered, while keeping the sample size unchanged. The data analysis method is IBM SPSS (Statistical Program for Social Science) version 20. The result is the effect of Leadership and Dynamic Capabilities on Knowledge Management presented by multiple regression equation: $Y=1,425+$ 0,031 X1 + 0,625 X2, which $Y=$ Knowledge Management, X1 = Leadership, and X2 = Dynamic Capabilities. The Dynamic Capabilities significantly affects Knowledge Management, but Leadership does not significantly affect Knowledge Management. Leadership variable has two functions, as Independent Variable but must be controlled and as the second Independent Variable or as Mediator.
\end{abstract}

Keywords: leadership, dynamic capabilities, knowledge management

\begin{abstract}
ABSTRAK
Penelitian ini bertujuan untuk mengetahui pengaruh Kepemimpinan dan Kapabilitas Dinamis terhadap penerapan Manajemen Pengetahuan dalam penyelenggaraan proses belajar mengajar di BINUS University. Responden penelitian adalah dosen dan karyawan BINUS University yang berjumlah 90 reponden. Teknik pengambilan sampel dilakukan dengan cara disproporsionate stratified random sampling, dengan jumlah subjek dari setiap strata tidak sama rata, tetapi jumlah sampel tidak berubah. Metode pengolahan data yang digunakan adalah IBM SPSS (Statistical Program for Social Science) version 20. Hasil penelitian menunjukkan pengaruh Kepemimpinan dan Kapabilitas Dinamis terhadap Manajemen Pengetahuan ditunjukkan oleh persamaan regresi linear berganda $Y=1,425+0,031 X 1+0,625 X 2$; dengan $Y=$ Manajemen Pengetahuan, $X 1=$ Kepemimpinan, $X 2=$ Kapabilitas Dinamis. Kapabilitas Dinamis berpengaruh secara signifikan terhadap Manajemen Pengetahuan, sedangkan Variabel Kepemimpinan pengaruhnya tidak signifikan terhadap Manajemen Pengetahuan. Variabel Kepemimpinan memiliki dua fungsi, yaitu: sebagai Independent Variable tetapi harus dikontrol dan sebagai Independent Variable kedua atau sebagai mediator.
\end{abstract}

Kata kunci: kepemimpinan, kapabilitas dinamis, manajemen pengetahuan 


\section{PENDAHULUAN}

Ditinjau kemajuannya, menurut Nizam (2013) saat ini Indonesia menduduki peringkat dunia keenam belas, memiliki 45 juta penduduk usia sekolah, 55 juta tenaga trampil, dan \$ 0,5 triliun peluang pasar untuk jasa, pertanian dan perikanan, sumber daya, dan pendidikan. Berdasarkan Proyeksi McKinsey and Company (2012), pada 2030 Indonesia akan menduduki peringkat dunia yang ke tujuh, dengan 135 juta penduduk usia sekolah, 113 juta tenaga trampil, dan \$1,8 triliun peluang pasar untuk jasa, pertanian dan perikanan, sumber daya, dan pendidikan. Melihat besarnya peluang pasar khususnya di bidang pendidikan, maka pendidikan perlu dibina dan dikembangkan baik kuantitasnya dan kualitasnya.

Penduduk usia sekolah yang jumlahnya sekitar 45 juta anak pada masa usia belajar difasilitasi oleh 95 perguruan tinggi negeri (PTN) dan sekitar 3.000 perguruan tinggi swasta (PTS). Jumlah PTS yang besar ini mampu menampung sekitar 70 persen anak Indonesia pada usia belajar, sedangkan yang mendapatkan kesempatan untuk memperoleh pendidikan di PTN hanya sekitar 30 persen. Besarnya jumlah anak pada usia belajar, dan adanya faktor pergeseran usia penduduk, serta kemajuan ekonomi menambah kemungkinan anak-anak dari keluarga menengah memasuki jenjang pendidikan tinggi, yang berakibat meningkatnya permintaan terhadap pendidikan tinggi.Tantangan terbesar adalah bagaimana menyediakan pendidikan tinggi dalam menghadapi begitu pesatnya pertumbuhan permintaan itu dan mengupayakan agar pendidikan tinggi yang sudah ada tetap baik mutunya dan berkelanjutan (sustainable) (Elfindri, 2013).

BINUS University, sebagai salah satu perguruan tinggi swasta mengalami persaingan yang sangat ketat, dalam lingkup domestik maupun global. Dalam menghadapi persaingan dalam era globalisasi PTS sebagai organisasi dituntut untuk meninggalkan paradigma resource-based competitivenesss, di mana organisasi yang dianggap unggul dan kompetitif ialah organisasi yang memiliki faktor-faktor produksi secara lengkap seperti modal, tanah, tenaga kerja, bangunan, lokasi, dan mulai untuk mempergunakan paradigma knowledge-based competitiveness (Suharti \& Hartanto, 2009), sebagai tumpuan baru berupa eksploitasi, dan pengelolaan ilmu pengetahuan yang ada pada setiap sumber daya manusianya, dan teknologi dengan tujuan untuk mencapai keunggulan dan daya saing pada tingkat yang paling optimal. Fenomena inilah yang disebut dengan konsep Knowlegde Management Ini berarti Knowledge Management merupakan hal penting untuk diterapkan di perguruan tinggi.

Penerapan KM di lingkungan perguruan tinggi merupakan sesuatu yang mutlak, namun penelitian empirik penerapan KM di institusi pendidikan tinggi masih sangat terbatas (Suharti \& Hartanto, 2009). Beberapa studi terbatas dalam konteks negara barat menunjukkan bahwa institusi pendidikan tinggi dapat bertransisi dari institusi pengetahuan menjadi institusi pembelajar melalui penerapan KM. Perguruan tinggi yang menerapkan manajemen pengetahuan mampu menempatkan diri dengan baik dalam menjawab tantangan persaingan dalam industri pendidikan di era globalisasi saat ini. Berdasarkan latar belakang masalah tersebut, penelitian tentang pengaruh kepemimpinan dan kapabilitas dinamis terhadap manajemen pengetahuan dilakukan. Penelitian ini dilakukan untuk mengevaluasi pengaruh kepemimpinan dan kapabilitas dinamis terhadap Manajemen Pengetahuan di BINUS University.

\section{Landasan Teori}

\section{Teori-teori Kepemimpinan}

Menurut Al-Zegaier (2012), ada sembilan tipe dasar kepemimpinan dari teori kepemimpinan. Teori sifat dari kepemimpinan (Trait theories of leadership) menjawab pertanyaan dengan 
memberikan spesifikasi atau identifikasi sifat, karakteristik, kemampuan, pola perilaku, atau keterampilan yang dimiliki atau ditunjukkan oleh pemimpin. Masalah dalam teori ini adalah selalu mengidentifikasikan karakteristik yang membedakan pemimpin dari orang-orang dengan sifat yang sama dengan yang bukan pemimpin (Bass, 1990). Teori manajemen dari kepemimpinan (Management theories of leadership) berhubungan terutama dengan kinerja organisasi atau kelompok. Tipe teori ini mencakup kepemimpinan transaksional, kepemimpinan transformasional, kepemimpinan demokratis, dsb). Masalah yang mendasar dari teori ini adalah masalah eksploitasi (Bass, 1990). Teori hubungan (Relationship theories) menjawab pertanyaan dengan mendefinisikan kepemimpinan sebagai hubungan antara orang-orang dengan keinginan dan kebutuhan bersama yang berjuang untuk tujuan bersama. Hubungan ini didefinisikan dengan konflik dan dengan pengaruh. Teori Proses (Process theories) menjawab pertanyaan dengan mendefinisikan kepemimpinan sebagai proses dari interaksi dinamis di antara orang-orang dengan etika yang berbeda-beda untuk menyelaraskan mereka dalam menyelesaikan masalah sosial khusus atau untuk menghasilkan secara evolusi perubahan sosial. Dalam teori ini pemimpin lebih dipandang simbol dari yang diinginkan oleh setiap orang dari pada sebagai pembuat / produsen hasil. Teori Perilaku (Behavioural theories) membahas beberapa celah dalam teori sifat dengan konsentrasi pada apa yang benar-benar dilakukukan oleh pemimpin bukan pada kualitas yang mereka miliki (Theory X dan Theory Y). Kepemimpinan partisipatif (Participative leadership) merekomendasikan gaya kepemimpinan yang melibatkan orang lain dalam proses kepemimpinan. Teori-teori ini (Gaya Kepemimpinan Lewin, Gaya Kepemimpinan Likert) menyarankan bahwa pemimpin mempunyai hak untuk menerima atau menolak perkataan dari bawahannya dalam proses kepemimpinan. Kepemimpinan Situasional (Situational leadership) menyarankan bahwa kepemimpinan adalah reaksi terhadap situasi di mana sedang dilaksanakan. Teori-teori ini (model normatif, model kepemimpinan berpusat-tindakan, kepemimpinan kesatuan, model kepemimpinan situasional Hersey and Blanchard, teori lintasan-tujuan, dsb.) menyarankan bahwa mungkin gaya kepemimpinan yang berbeda memerlukan level yang berbeda pada organisasi yang sama. Teori kontingensi (Contingency theories) memperhalus sudut pandang situasional dengan berfokus pada identifikasi variabel-variabel situasional yang menentukan gaya kepemimpinan yang paling tepat untuk menyesuaikan dengan keadaan tertentu. Teori Kepemimpinan House's Path-Goal dikembangkan oleh Robert House dan memiliki akar-akar dalam teori harapan dari motivasi. Teori ini berdasarkan pada alasan bahwa persepsi karyawan akan harapan (expectancy) antara usaha dan kinerjanya sangat dipengaruhi oleh perilaku pemimpinnya. Keempat gaya kepemimpinan menurut House adalah: directive, supportive, participative, dan achievement-oriented.

\section{Definisi Kepemimpinan Transaksional dan Transformasional}

Menurut Hamilton (2010), berdasarkan teori kepemimpinan, kepemimpinan transaksional dan kepemimpinan transformasional termasuk dalam teori kepemimpinan manajemen (Al-Zegaier, 2012). Kepemimpinan Transaksional secara sederhana diringkas sebagai transaksi antara pemimpin dan bawahan, dalam usaha untuk meningkatkan kinerja. Secara umum didefinisikan sebagai kepemimpinan yang berdasarkan transaksi antara manajer dan pekerja (Bass, 1990).

Bass (1990) mendeskripsikan Kepemimpinan Transaksional secara terperinci sebagai perubahan dalam tingkat atau peningkatan marginal yang dapat dilihat sebagai hasil dari kepemimpinan yaitu proses pertukaran: suatu transaksi yang bawahan mencapai kinerja dan mencapai kontrak eksplisit atau implisit dengan pimpinannya. Kepemimpinan Transaksional sebagai persyaratan dan kondisi eksplisit khusus dari suatu tugas, dilengkapi dengan penghargaan (reward) untuk memenuhi persyaratan tersebut dan bahwa memenuhi persyaratan adalah melengkapi transaksi tersebut. Sedangkan Kepemimpinan Transformasional merupakan tipe kepemimpinan yang menginspirasi dan mentransformasi pekerja dalam rangka meningkatkan kinerjanya. Bass (1990) menjelaskan Transformasional terjadi jika pemimpin memperluas dan mengangkat kepentingan dari pekerja, ketika mereka membuat kesadaran dan penerimaan dari tujuan dan misi kelompok, dan ketika mereka memadukan para pekerja untuk melihat lebih jauh dari sekedar kepentingan diri sendiri untuk kebaikan kelompok. 


\section{Multifactor Leadership Questionnaire (MLQ)}

Bass (1990) mengembangkan Multifactor Leadership Questionnaire (MLQ) untuk tingkat pemimpin menunjukkan kepemimpinan transaksional dan transformasional dan tingkat pengikut/bawahan (follower) puas terhadap efektifitas kepemimpinan pemimpinnya. MLQ mengukur berbagai tipe kepemimpinan dari pemimpin pasif sampai pemimpin yang memberikan penghargaan kontingensi kepada para pengikut-pengikutnya, sampai pemimpin yang mentransformasikan pengikutnya menjadi pemimpin bagi dirinya sendiri. MLQ menawarkan pemikiran lengkap dari 9 faktor kepemimpinan, yaitu Kepemimpinan Transformasional: Atribut Ideal (Idealized Attributes), Perilaku Ideal (Idealized Behaviour), Motivasi Inspirasional (Inspirational Behaviour), Stimulasi Intelektual (Intellectual Stimulation), Pertimbangan Individual (Individualized Stimulation); Kepemimpinan Transaksional: Penghargaan kontingensi, Manajemen dengan Pengecualian (Management-by-Exception) Aktif; Perilaku menghindar Pasif (Passive - Avoidant Behaviours): Manajemen dengan pengecualian (Management-by-Exception) Pasif, Kepemimpinan bergaya lebih bebas (Laissez-Faire).

\section{Konsep Kapabilitas Dinamis}

Kapabilitas Dinamis didefinisikan dari dua suku kata, yaitu kapabilitas dan dinamis. Istilah dinamis menunjukkan kapasitas untuk memperbarui kompetensi-kompetensi untuk mencapai kesesuaian dengan perubahan lingkungan bisnis; tanggapan tertentu diperlukan ketika laju perubahan teknologi cepat, dan kompetisi mendatang dan kondisi pasar sulit ditentukan. Istilah kapabilitas menekankan aturan kunci dari manajemen dalam beradaptasi, mengintegrasi, dan merekonfigurasi secara tepat ketrampilan-ketrampilan internal dan eksternal organisasi, sumber daya, dan kompetensi fungsional untuk menyesuaikan dengan persyaratan perubahan lingkungan.

Konsep kapabilitas dinamis dikembangkan secara eksplisit dalam suatu studi oleh Teece, Pisano, dan Shuen (1997). Konsep ini secara formal dipublikasikan pada 1994 oleh Teece dan Pisano. Mereka menerangkan bahwa RBV (Resources Based View) tidak bisa untuk melengkapi penjelasan bagaimana suatu perusahaan sukses dalam mendemonstrasikan inovasi produk yang responsif, cepat, dan fleksibel dan menyebarkan kembali kompetensi-kompetensi internal dan eksternal. Secara eksplisit berargumentasi bahwa pandangan tentang kapabilitas dinamis bisa mengatasi keterbatasan dari RBV. Mereka mendefinisikan kapabilitas dinamis sebagai kemampuan untuk mengintegrasi, membangun, dan merekonfigurasi kompetensi-kompetensi internal dan eksternal untuk menghadapi perubahan lingkungan yang cepat.

\section{Tinjauan Pustaka Konstruk Manajemen Pengetahuan}

Dalam perspektif integrasi, menajemen pengetahuan menggambarkan sumber daya yang ada dalam organisasi yang mungkin sudah diterapkan pada praktek-prakterk sistem informasi yang baik, manajemen informasi perubahan organisasional, dan manajemen sumber daya manusia. Secara khusus dilihat dari perspektif sumber daya manusia, manajemen pengetahuan merupakan suatu proses untuk memperoleh, menangkap, berbagi, atau menggunakan pengetahuan, di mana pun tempatnya, untuk meningkatkan pembelajaran dan kinerja dalam organisasi. Manajemen pengetahuan merupakan manajemen sistematik dan eksplisit dari pengetahuan vital dan proses-proses yang berhubungan, dari menciptakan, mengumpulkan, mengorganisasikan, difusi, penggunaan dan eksploitasi, dalam mengejar tujuan organisasi. Dari perspektif sistem informasi, Martin (2000) mendefinisikan manajemen pengetahuan sebagai semua metode, instrumen, dan alat dalam pendekatan yang holistik berkontribusi terhadap promosi dari proses pengetahuan inti.

Perspektif kedua dalam mendefinisikan manajemen pengetahuan adalah perspektif strategi (Uit Beijerse, 2000). Menurut perspektif ini manajemen pengetahuan dianggap sebagai pencapaian tujuan organisasi dengan membuat faktor produktif pengetahuan. Definisi manajemen pengetahuan 
sebagai tindakan untuk meningkatkan cara-cara dimana perusahaan-perusahaan menghadapi lingkungan dengan turbulensi tinggi dapat memobilisasi basis pengetahuan (atau mendaya-ungkit aset pengetahuan) dalam rangka memastikan inovasi yang kontinu.

Dari definisi tersebut tampak bahwa kemajuan dalam manajemen pengetahuan perlu mengadopsi integrasi perspektif interdisipliner dan strategis (Jashapara, 2011). Tujuan strategis dari aktivitas-aktivitas manajemen pengetahuan adalah untuk meningkatkan modal intelektual dan mempertinggi kinerja organisatoris. Terdapat dimensi manusia dari pengembangan pengetahuan individual, tim, dan organisasi dan semuanya terjadi secara mendasar melalui proses pembelajaran yang berbeda.

Dari perspektif yang ketiga, yaitu interdisipliner, manajemen pengetahuan dapat didefinisikan sebagai proses pembelajaran efektif dihubungkan dengan eksplorasi, eksploitasi, dan berbagi pengetahuan manusia (tersembunyi dan terang-terangan) yang menggunakan teknologi dan lingkungan budaya yang tepat untuk meningkatkan modal intelektual dan kinerja. Dalam manajemen pengetahuan, dikenal isrilah-istilah data, information, pengetahuan, dan kebijakan (Jashapara, 2011). Data didefinisikan sebagai fakta atau benda yang diketahui yang digunakan sebagai basis inferensia atau reckoning. Sedangkan definisi informasi adalah sesuatu yang menceritakan atau aktivitas menginformasikan atau menceritakan. Informasi dapat dianggap sebagai data yang terorganisir secara sistematis.

\section{METODE}

Jenis data untuk semua variabel adalah data kuantitatif. Sumber data adalah primer (dari kuesioner). Teknik Pengumpulan Data menggunakan sumber data primer yaitu kuesioner. Data sekunder diperoleh melalui studi literatur dengan cara melihat, membaca, dan mencatat buku-buku, Internet, dan jurnal ilmiah. Teknik pengambilan sampel dilakukan dengan cara disproporsionate stratified random sampling dengan jumlah subjek dari setiap strata tidak sama rata tetapi jumlah sampel tidak berubah. Sampel dalam penelitian ini berjumlah 90 terdiri dari dosen dan karyawan. Metode analisis data menggunakan regresi linier berganda dan korelasi.

\section{Kerangka Konseptual}

Untuk membentuk kerangka konseptual, perlu dijelaskan mengenai jenis-jenis operasional variabel. Menurut Putong (2007) ada dua jenis variabel, yaitu variabel dependen (kriteria/respons) dan variabel independen (prediktor). Variabel dependen terdiri dari tiga variabel yaitu variabel dependen tunggal, variabel dikotomi, dan variabel multiple, sedangkan variabel independen terdiri dari variabel anteseden (pendahulu), variabel intervening (partial mediator dan full mediator), dan variabel interaction (homologizer, Quasi, dan Pure Moderator). Kerangka konseptual (Gambar 1) dibuat berdasarkan hubungan antara variabel-variabel kepemimpinan, kapabilitas dinamis, dan manajemen pengetahuan. Kepemimpinan, dan kapabilitas dinamis masing-masing berpengaruh langsung terhadap Manajemen Pengetahuan (H1) dan (H2).

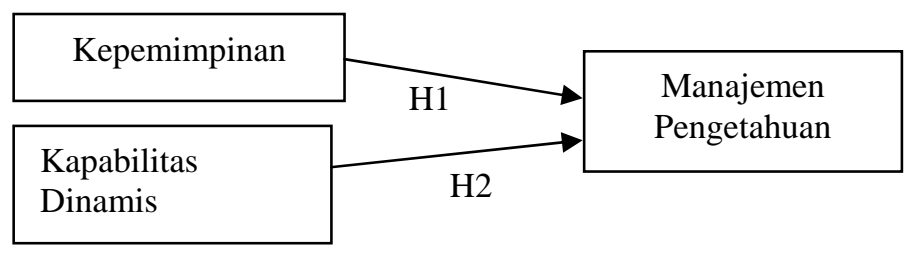

Gambar 1 Kerangka Konseptual 
Berdasarkan kerangka konseptual yang diusulkan, disusun dua hipotesis yang akan diteliti yaitu H1 (pengaruh kepemimpinan terhadap manajemen pengetahuan), H2 (pengaruh kapabilitas dinamis terhadap manajemen pengetahuan).

\section{H1: Kepemimpinan berpengaruh positif terhadap manajemen pengetahuan}

(Crawford, 2003; Ali, 2006; Nguyen, Neck, \& Nguyen, 2009; Ryan, Zhang, Prybutok, \& Sharp, 2012; dan Al-Zegair, 2012).

\section{H2: Kapabilitas dinamis berpengaruh positif terhadap manajemen pengetahuan}

(Gooderham, 2007; Nguyen \& Neck, 2008; Easterby-Smith \& Prieto, 2008).

\section{Objek dan Konteks Penelitian}

Subjek penelitian adalah dosen dan karyawan BINUS University dengan objek penelitian (konstruk yang diteliti) Kepemimpinan, Kapabilitas Dinamis, dan Manajemen Pengetahuan.

\section{Populasi dan sampel penelitian}

Populasi merupakan objek dan subjek yang memenuhi syarat-syarat tertentu berkaitan dengan masalah penelitian. Sampel adalah bagian dari populasi yang mempunyai ciri-ciri atau keadaan tertentu yang akan diteliti (Riduwan \& Kuncoro, 2007). Populasi ialah kumpulan yang lengkap dari elemen-elemen yang sejenis akan tetapi dapat dibedakan karena karakteristiknya. Sampling ialah cara pengumpulan data; jika hanya elemen sampel yang diteliti, hasilnya merupakan data perkiraan atau estimasi, jadi bukan data sebenarnya (Supranto, 2007).

\section{Operasionalisasi Konstruk}

Operasionalisasi konstruk atau variabel merupakan penjelasan pengertian dari teori variabel, sehingga dapat diamati dan diukur dengan menentukan hal-hal yang diperlukan untuk mencapai tujuan tertentu.Variabel adalah karakteristik yang dapat diamati dan sesuatu (objek) dan mampu memberikan macam-macam nilai atau beberapa katagori (Riduwan \& Kuncoro, 2007). Variabel-variabel pada penelitian ini merupakan variabel laten atau konstruk laten, yang merupakan konsep abstrak, hanya dapat diamati secara tidak langsung, yaitu melalui indikator-indikatornya. Indikator-indikator diturunkan dari penelitian-penelitian sebelumnya, dengan menggunakan Skala Likert $1-5$. Menurut Sugiyono (2010), skala Likert digunakan untuk mengukur sikap, pendapat, dan persepsi seseorang atau sekelompok orang tentang fenomena sosial. Skala ini menggunakan respons yang dikategorikan dalam lima macam kategori jawaban, yaitu: Sangat Setuju (SS), Setuju (S), Netral (N), Tidak Setuju (TS), Sangat tidak setuju (STS).

Empat variabel penelitian ditunjukkan pada Tabel 1.

Tabel 1 Operasionalisasi Variabel

\begin{tabular}{|l|l|}
\hline \multicolumn{1}{|c|}{ Variabel } & \multicolumn{1}{c|}{ Indikator } \\
\hline Kepemimpinan & - Penghargaan kontingensi \\
Transaksional & Penghargaan untuk usaha(effort) \\
(Bass dalam & Menjanjikan penghargaan untuk kinerja yang baik \\
Hamilton, 2010) & Mengakui prestasi \\
& - Manajemen dengan pengecualian (aktif) \\
& Pemimpin melihat dan mencari penyimpangan dari aturan-aturan daristandar \\
& Mengambil tindakan perbaikan \\
& - Manajemen dengan pengecualian (pasif) \\
& Pemimpin campur tangan hanya jika standarnya tidak terpenuhi \\
& - Kepemimpinan Laissez-faire \\
\hline
\end{tabular}




\begin{tabular}{|c|c|}
\hline & $\begin{array}{l}\text { Pemimpin melepaskan tanggung jawab } \\
\text { Pemimpin menghindari pengambilan keputusan. } \\
\text { Menunda penyelesaian masalah yang penting }\end{array}$ \\
\hline $\begin{array}{l}\text { Kepemimpinan } \\
\text { Transformasional } \\
\text { (Bass dalam } \\
\text { Hamilton, 2010) }\end{array}$ & $\begin{array}{l}\text { - Pengaruh Idealis (Idealized Influence, II) } \\
\text { Membuat orang lain merasa baik } \\
\text { Membuat orang lain bangga } \\
\text { Mendapatkan ketulusan dari bawahan } \\
\text { - Motivasi Inspirasional (Inspirational Motivation, IM) } \\
\text { Pemimpin mengkomunikasikan tujuannya } \\
\text { Pemimpin memanipulasi imajinasi } \\
\text { Pemimpin membantu orang lain menemukan arti dari pekerjaan } \\
\text { - Stimulasi Intelektual (Intellectual Stimulation, IS) } \\
\text { Kemampuan pemimpin untuk membuat orang berpikir tentang cara baru untuk melakukan } \\
\text { pekerjaan } \\
\text { Pemimpin mempunyai cara baru untuk melihat pekerjaan } \\
\text { Pemimpin mempunyaicara untuk menjadi kreatif dalam metode penyelesaian masalah yang } \\
\text { dimiliki. } \\
\text { - Pertimbangan Individual, Individual Consideration, IC) } \\
\text { Pemimpin mendorong pengembangan individual } \\
\text { Pemimpin memberikan umpan balik kepada bawahannya. } \\
\text { Pemimpin melibatkan pekerja ke dalam tim atau kelompok }\end{array}$ \\
\hline $\begin{array}{l}\text { Kapabilitas } \\
\text { Dinamis (Jiao, } \\
\text { Alon, \& Kwong } \\
\text { 2011) }\end{array}$ & $\begin{array}{l}\text { - Environmental Sensing Capability } \\
\text { Pemahaman aturan operasional } \\
\text { Pengenalan terhadap tren perubahan } \\
\text { Membangun perencanan untuk tanggapan yang cepat } \\
\text { Komunikasi yang sering dengan stakeholder (pesaing, pelanggan, pemasok, dll) } \\
\text { - Changing and Renewal Capability } \\
\text { Dukungan organisasi terhadap inovasi pekerja } \\
\text { Dorongan untuk budaya inovatif } \\
\text { Stimulasi dan penghargaan pada kapabilitas inovasi } \\
\text { Memberi semangat kepada pekerja } \\
\text { - Technological Flexibility Capabilities } \\
\text { Teknologi berguna bagi peningkatan produk / jasa } \\
\text { Teknologi cocok untuk berbagai produk dan jasa } \\
\text { Teknologi mempercepat pengenalan pelanggan terhadap produk dan jasa } \\
\text { - Organizational Flexibility Capability } \\
\text { Departemen mengizinkan terobosan prosedur kerja formal } \\
\text { Operasi kerja internal setiap orang berbeda } \\
\text { Mekanisme dan saluran komunikasi internal yang halus } \\
\text { Institusi selalu lebih cepat dari pesaing dalam memanfaatkan peluang }\end{array}$ \\
\hline $\begin{array}{l}\text { Manajemen } \\
\text { Pengetahuan }\end{array}$ & $\begin{array}{l}\text { - Proses Akuisisi (Inkpen dalam Nguyen \& Neck, 2008) } \\
\text { Memiliki proses memperoleh pengetahuan tentang pelanggan } \\
\text { Menurunkan pengetahuan baru dari pengetahuan yang sudah ada } \\
\text { Memiliki proses akuisisi pengetahuan tentang pemasok } \\
\text { Memiliki proses mendistribusikan pengetahuan ke seluruh organisasi } \\
\text { Memiliki proses memperoleh pengetahuan tentang produk /layanan baru dalam institusi } \\
\text { Memiliki proses pertukaran antar individu } \\
\text { - Proses Konversi (Gold, Malhorta, \& Segars, } 2001 \text { dalam Nguyen \& Neck 2008) } \\
\text { Memiliki proses untuk menyaring pengetahuan } \\
\text { Memiliki proses untuk mentransfer pengetahuan organisasi kepada individu } \\
\text { Memiliki proses untuk menyerap pengetahuan dari individu ke dalam organisasi } \\
\text { Memiliki proses untuk mengintegrasi sumber-sumber dan tipe-tipe pengetahuan yang berbeda } \\
\text { Memiliki proses pengorganisasian pengetahuan (penyimpanan/file) } \\
\text { Memiliki proses untuk menggantikan pengetahuan yang usang } \\
\text { - Proses Aplikasi (Gold, Malhorta, \& Segars, 2001 dalam Nguyen \& Neck, 2008) } \\
\text { Memiliki proses untuk menggunakan pengetahuan dalam pengembangan produk/layanan baru } \\
\text { Memiliki proses untuk menggunakan pengetahuan dalam menyelesaikan masalah baru } \\
\text { Mencocokkan sumber-sumber pengetahuan dengan masalah-masalah dan tantangan-tantangan } \\
\text { Menggunakan pengetahuan untuk meningkatkan efisiensi } \\
\text { Menggunakan pengetahuan untuk mengatur arah strategic } \\
\text { Bisa menempatkan dan mengaplikasikan pengetahuan pada perubahan kondisi persaingan } \\
\text { Mengambil keuntungan dari pengetahuan baru } \\
\text { - Proses Proteksi (Gold, Malhorta, \& Segars, 2001dalam Nguyen \& Neck 2008) }\end{array}$ \\
\hline
\end{tabular}




\begin{tabular}{|l|l|}
\hline & $\begin{array}{l}\text { Memiliki proses untuk melindungi pengetahuan dari penggunaan yang tidak tepat di dalam } \\
\text { organisasi } \\
\text { Memiliki proses untuk melindungi pengetahuan dari penggunaan yang tidak tepat di luar } \\
\text { organisasi } \\
\text { Memiliki proses untuk melindungi pengetahuan dari pencurian di dalam organisasi } \\
\text { Memiliki proses untuk melindungi pengetahuan dari pencurian di luar organisasi } \\
\text { Memiliki kebijakan dan prosedur yang luas untukk melindungi rahasia bisnis organisasi } \\
\text { Menilai dan melindungi pengetahuan yang melekat pada individu } \\
\text { Mengkomunikasikan secara jelas (menciptakan penghargaan terhadap) pentingnya melindungi } \\
\text { pengetahuan }\end{array}$ \\
\hline
\end{tabular}

\section{Metode Analisis Data}

Hasil Penelitian berupa kuesioner diolah menggunakan perangkat lunak IBM SPSS Statistics 20. IBM SPSS Statistics adalah suatu produk yang terintegrasi yang mengolah kesluruhan proses analisis, dari perencanaan, pengumpulan, dan analisis data, pelaporan dan pengembangannya.

\section{HASIL DAN PEMBAHASAN}

\section{Uji Reliabilitas}

Reliabilitas (Tabel 2) menggambarkan pada kemantapan dan keajegan alat ukur yang digunakan. Suatu alat ukur dikatakan memiliki reliabilitas atau keajegan yang tinggi atau dapat dipercaya, apabila alat ukur tersebut stabil sehingga dapat diandalkan dan dapat digunakan untuk meramalkan (predictability) (Sekaran \& Bougi, 2010). Pada penelitian ini, uji reliabilitas menggunakan metode Cronbach Alpha (Tabel 3). Reliabilitas diukur dengan menguji tingkat konsistensi hasil pengukuran jika dilakukan pengukuran ulang. Andal atau tidaknya suatu data dapat dilihat dari koefisien alpha yang dihasilkan. Data yang mendekati angka 1 (satu) dapat dikatakan memiliki keandalan tinggi. Menurut Hair (2010), nilai koefisien Cronbach Alpha yang mendekati 1 menunjukkan bahwa hasil yang diperoleh semakin konsisten sehingga dikatakan mempunyai reliabilitas yang tinggi. Suatu data dikatakan akurat jika nilai koefisien Cronbach Alpha minimum adalah 0,60 (Malhotra, 2007). Uji reliabilitas pada penelitian ini menggunakan program SPSS versi 20.0 .

Tabel 2 Rangkuman Pengolahan Data

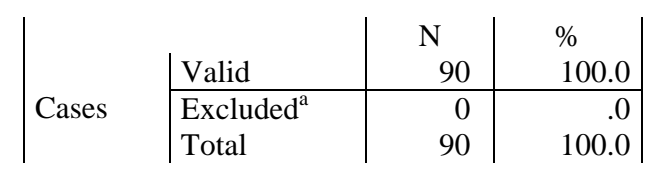

a. Listwise deletion based on all variables in the procedure

Tabel 3 Reliability Statistics

\begin{tabular}{cc}
\hline Cronbach's Alpha & N of Items \\
\hline .901 & 3 \\
\hline
\end{tabular}

\section{Statistik Deskriptif}

Rata-rata Kepemimpinan adalah 3,9189 dengan standar deviasi 0,5032. Nilai minimum 2,36 dan nilai maksimum 4,91. Rata-rata Kapabilitas dinamis adalah 3,9598 dengan standar deviasi 
0,47892. Nilai minimum 2,50 dan nilai maksimum 5.00. Rata-rata Manajemen Pengetahuan 4,0222 dengan standar deviasi 0,39383. Nilai minimum 3,04 dan nilai maksimum 5,00. (lihat Tabel 4)

Tabel 4 Statistik Deskriptif

\begin{tabular}{lccccc}
\hline & N & Minimum & Maximum & Mean & Std. Deviation \\
\hline Kepemimpinan & 90 & 2.36 & 4.91 & 3.9189 & .50302 \\
KapabilitasDinamis & 90 & 2.50 & 5.00 & 3.9598 & .47892 \\
ManajemenPengetahuan & 90 & 3.04 & 5.00 & 4.0222 & .39383 \\
Valid N (listwise) & 90 & & & & \\
\hline
\end{tabular}

\section{Regresi}

Variabel entered menunjukkan bahwa tidak ada variable yang dikeluarkan (removed), atau dengan kata lain kedua variabel bebas dimasukkan dalam perhitungan regresi.

Tabel 5 Variables Entered/Removed ${ }^{\mathrm{a}}$

\begin{tabular}{lccc}
\hline Model & Variables Entered & Variables Removed & Method \\
\hline 1 & Kapabilitas Dinamis, Kepemimpinan & & B \\
a. Dependent Variable: Manajemen Pengetahuan & & Enter \\
b. All requested variables entered. & & \\
\end{tabular}

Angka R square adalah 0.629. Ini berarti 62,9 \% Manajemen Pengetahuan institusi bisa dijelaskan oleh variabel Kepemimpinan dan Kapabilitas. Sedangkan sisanya (100\% - 62,9\% = 37,1 \%) dijelaskan oleh sebab/faktor yang lain. Standard error of estimate adalah 0,24265. (lihat Tabel 6)

Tabel 6 Model Summary

\begin{tabular}{lcccc}
\hline Model & $\mathbf{R}$ & R Square & Adjusted R Square & Std. Error of the Estimate \\
\hline 1 & $.793^{\mathrm{a}}$ & .629 & .620 & .24265 \\
\hline a. Predictors: (Constant), Kepemimpinan, KapabilitasDinamis
\end{tabular}

Dari uji ANOVA atau $F$ test (Tabel 7), diperoleh $F$ hitung adalah 73.723 dengan tingkat signifikansi 0.000 . Karena probabilitas $(0.000)$ jauh lebih kecil dari 0.05 , maka model regresi bisa dipakai untuk memprediksi Manajemen Pengetahuan. Atau bisa dikatakan, Kepemimpinan dan Kapabilitas Dinamis secara bersama-sama berpengaruh terhadap Manajemen Pengetahuan.

Tabel 7 ANOVA $^{\mathrm{a}}$

\begin{tabular}{lccccc}
\hline Model & Sum of Squares & Df & Mean Square & F & Sig. \\
\hline Regression & 8.682 & 2 & 4.341 & 73.723 & $.000^{\mathrm{b}}$ \\
1 & 5.123 & 87 & .059 & & \\
Residual & 13.804 & 89 & & & \\
Total & a. Dependent Variable: ManajemenPengetahuan & & \\
b. Predictors: (Constant), KapabilitasDinamis, Kepemimpinan & &
\end{tabular}


Persamaan regresi yang dapat dilihat dari Tabel 8, yaitu: $\mathrm{Y}=1,425+0,625 \mathrm{X} 1+0,031 \mathrm{X} 2$; dengan Y = Manajemen Pengetahuan, X1 = Kapabilitas Dinamis, dan X2 = Kepemimpinan. Konstanta sebesar 1,425 menyatakan bahwa jika tidak ada Kepemimpinan atau Kapabilitas Dinamis, Manajemen Pengetahuan nilainya 1,425 (maksimum 5). Koefisien regresi X1 sebesar 0,625 menyatakan bahwa setiap penambahan (tanda + ) 1 skala (dari skala Likert 5) Kapabilitas Dinamis, maka Manajemen Pengetahuan akan meningkat 0,625 skala. Koefisien regresi X2 sebesar 0,031 menyatakan bahwa setiap penambahan (+) 1 skala Kepemimpinan akan meningkatkan Manajemen sebesar 0,031 skala. Uji “t” untuk menguji signifikansi konstanta dan variabel dependen Manajemen Pengetahuan.

Tabel 8 Coefficients ${ }^{\mathrm{a}}$

\begin{tabular}{|c|c|c|c|c|c|c|}
\hline & \multirow{2}{*}{ Model } & \multicolumn{2}{|c|}{$\begin{array}{l}\text { Unstandardized } \\
\text { Coefficients }\end{array}$} & \multirow{2}{*}{$\begin{array}{c}\begin{array}{c}\text { Standardized } \\
\text { Coefficients }\end{array} \\
\text { Beta }\end{array}$} & \multirow{2}{*}{$\mathbf{T}$} & \multirow{2}{*}{ Sig. } \\
\hline & & B & $\begin{array}{l}\text { Std. } \\
\text { Error }\end{array}$ & & & \\
\hline \multirow{3}{*}{1} & (Constant) & 1.425 & .219 & & 6.513 & .000 \\
\hline & KapabilitasDinamis & .625 & .094 & .761 & 6.637 & .000 \\
\hline & Kepemimpinan & .031 & .090 & .039 & .342 & .733 \\
\hline
\end{tabular}

\section{Kapabilitas Dinamis}

Hipotesis: $\quad$ Ho $=$ Koefisien regresi tidak signifikan . Ha $=$ Koefisien regresi signifikan.

Jika probabilitas $>0,05$, Ho diterima. Jika probabilitas $<0,05$, Ho ditolak. Dalam SPSS, biasanya kata probabilitas diwakili dengan kata signifikan/sig. Terlihat bahwa Sig. T adalah 0.000, atau probabilitas jauh lebih kecil dari 0.05 , maka Ho ditolak, atau koefisien regresi signifikan, atau Kapabilitas Dinamis berpengaruh secara signifikan terhadap Manajemen Pengetahuan.

\section{Kepemimpinan}

Hipotesis: $\quad$ Ho $=$ Koefisien regresi tidak signifikan.

Ha = Koefisien regresi signifikan.

Jika probabilitas $>0,05$, Ho diterima. Jika probabilitas $<0,05$, Ho ditolak. Terlihat bahwa Sig. $\mathrm{T}$ adalah 0.733, atau probabilitas lebih besar dari 0.05, maka Ho diterima, atau koefisien regresi tidak signifikan, atau Kepemimpinan tidak berpengaruh secara signifikan terhadap Manajemen Pengetahuan.

\section{Korelasi}

Pertama, besar hubungan antara variabel Kapabilitas Dinamis dengan Manajemen Pengetahuan yang dihitung dengan koefisien korelasi adalah 0.793. Sedangkan korelasi variabel Kepemimpinan dengan Manajemen Pengetahuan adalah 0,644. Secara teoretis, karena korelasi antara Kapabilitas Dinamis dengan Kepemimpinan lebih besar, maka variabel Kapabilitas Dinamis lebih berpengaruh terhadap Manajemen Pengetahuan dibanding variabel Kepemimpinan. Kedua, terjadi korelasi yang cukup kuat antara variabel Kepemimpinan dengan Kapabilitas Dinamis, yaitu 0.822. Hal ini menandakan adanya multikolineritas atau korelasi di antara variabel bebas. Ketiga, tingkat signifikansi koefisien korelasi satu sisi dari output (diukur dari probabilitas) menghasilkan angka 
0.000 atau praktis 0 . Karena probabilitas jauh di bawah 0.05 , maka korelasi di antara variabel Manajemen Pengetahuan dengan Kepemimpinan dan Kapabilitas Dinamis sangat nyata. (lihat Tabel 9)

Tabel 9 Correlations

\begin{tabular}{llccc}
\hline & Manajemen & $\begin{array}{c}\text { Kepemimpinan } \\
\text { Pengetahuan }\end{array}$ & $\begin{array}{c}\text { Kapabilitas } \\
\text { Dinamis }\end{array}$ \\
\hline \multirow{3}{*}{ ManajemenPengetahuan } & Pearson Correlation & 1 & $.664^{* *}$ & $.793^{* *}$ \\
& Sig. (2-tailed) & & .000 & .000 \\
& $\mathrm{~N}$ & 90 & 90 & 90 \\
Kepemimpinan & Pearson Correlation & $.664^{* *}$ & 1 & $.822^{* *}$ \\
& Sig. (2-tailed) & .000 & 90 & .000 \\
& N & 90 & $.822^{* *}$ & 90 \\
KapabilitasDinamis & Pearson Correlation & $.793^{* *}$ & .000 & 1 \\
& Sig. (2-tailed) & .000 & 90 & 90 \\
\hline
\end{tabular}

**. Correlation is significant at the 0.01 level (2-tailed).

\section{Analisis Lanjut untuk Dependent Variable yang tidak Signifikan (Kepemimpinan)}

Berdasarkan Tabel 10, Kapabilitas Dinamis dengan analisis regresi linear sederhana berpengaruh secara signifikan terhadap Manajemen Pengetahuan. Hal ini ditunjukkan oleh kolom "sig" $=0.000$ (jauh lebih kecil dari 0,05).

Tabel 10 Coefficients $^{\mathrm{a}}$

\begin{tabular}{llrccccc}
\hline \multirow{2}{*}{ Model } & \multicolumn{2}{c}{$\begin{array}{c}\text { Unstandardized } \\
\text { Coefficients }\end{array}$} & $\begin{array}{c}\text { Standardized } \\
\text { Coefficients }\end{array}$ & \multirow{2}{*}{ t } & Sig. \\
\cline { 2 - 5 } & \multicolumn{1}{c}{ B } & Std. Error & Beta & & \\
\hline \multirow{2}{*}{1} & (Constant) & 1.441 & .305 & & & 4.726 & .000 \\
& Kapabilitas Dinamis & .652 & .076 & .793 & & 8.528 & .000 \\
\hline
\end{tabular}

a. Dependent Variable: Manajemen Pengetahuan

Dari Tabel 11, Kepemimpinan dengan analisis regresi linear sederhana berpengaruh secara signifikan terhadap Manajemen Pengetahuan. Hal ini ditunjukkan oleh kolom "sig" $=0.000$ (jauh lebih kecil dari 0,05).

Tabel 11 Coefficients $^{\mathrm{a}}$

\begin{tabular}{llrcccc}
\hline \multirow{2}{*}{ Model } & \multicolumn{2}{c}{$\begin{array}{c}\text { Unstandardized } \\
\text { Coefficients }\end{array}$} & $\begin{array}{c}\text { Standardized } \\
\text { Coefficients }\end{array}$ & \multirow{2}{*}{ t } & Sig. \\
\cline { 3 - 5 } & & B & Std. Error & Beta & & \\
\hline \multirow{2}{*}{1} & (Constant) & 1.985 & .353 & & 5.627 & .000 \\
& Kepemimpinan & .520 & .089 & .664 & 5.825 & .000 \\
\hline
\end{tabular}

a. Dependent Variable: ManajemenPengetahuan 
Dari Tabel 12, jika Kepemimpinan sebagai Dependent Variable dan Kapabilitas Dinamis sebagai Independent Variable, Kepemimpinan berpengaruh secara signifikan terhadap Kapabilitas Dinamis. Hal ini ditunjukkan oleh kolom "sig” 0,000 (jauh lebih kecil dari 0,05).

Tabel 12 Coefficients $^{\mathrm{a}}$

\begin{tabular}{llcccrc}
\hline \multirow{2}{*}{ Model } & \multicolumn{2}{c}{$\begin{array}{c}\text { Unstandardized } \\
\text { Coefficients }\end{array}$} & $\begin{array}{c}\text { Standardized } \\
\text { Coefficients }\end{array}$ & \multirow{2}{*}{ t } & Sig. \\
\cline { 2 - 5 } & \multicolumn{1}{c}{ B } & Std. Error & Beta & & \\
\hline \multirow{2}{*}{1} & (Constant) & .502 & .255 & & 1.971 & .052 \\
& Kapabilitas Dinamis & .863 & .064 & .822 & 13.524 & .000 \\
\hline a. Dependent Variable: Kepemimpinan & & & &
\end{tabular}

Dari Tabel 13, jika Manajemen Pengetahuan sebagai Dependent Variable dan Kepemimpinan sebagai Independent Variable, Kepemimpinan berpengaruh secara signifikan terhadap Manajemen Pengetahuan. Hal ini ditunjukkan oleh kolom “sig” 0,000 (jauh lebih kecil dari 0,05).

Tabel 13 Coefficients ${ }^{\mathrm{a}}$

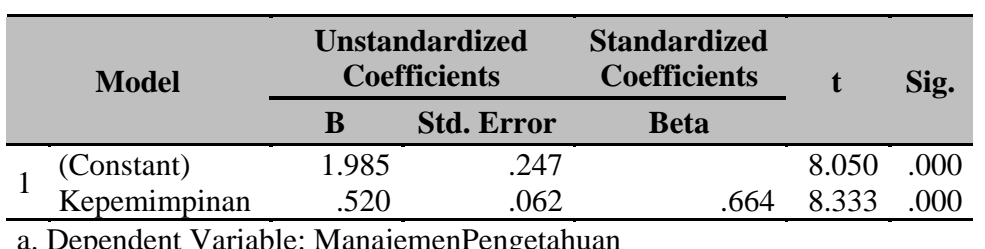

Berdasarkan analisis-analisis tersebut dan berdasarkan Tabel 14, variabel Kepemimpinan memiliki dua fungsi, yaitu sebagai independent variable, tetapi harus dikontrol dan sebagai independent variable kedua atau sebagai mediator.

Tabel 14 Correlations

\begin{tabular}{|c|c|c|c|c|}
\hline \multicolumn{3}{|c|}{ Control Variables } & \multirow{2}{*}{$\begin{array}{c}\begin{array}{c}\text { Manajemen } \\
\text { Pengetahuan }\end{array} \\
1.000\end{array}$} & \multirow{2}{*}{$\begin{array}{c}\begin{array}{c}\text { Kapabilitas } \\
\text { Dinamis }\end{array} \\
.580\end{array}$} \\
\hline \multirow{6}{*}{ Kepemimpinan } & & Correlation & & \\
\hline & Manajemen Pengetahuan & Significance (2-tailed) & & .000 \\
\hline & & Df & 0 & 87 \\
\hline & & Correlation & .580 & 1.000 \\
\hline & Kapabilitas Dinamis & Significance (2-tailed) & .000 & . \\
\hline & & Df & 87 & 0 \\
\hline
\end{tabular}

\section{SIMPULAN}

Hubungan antara variabel-variabel Kepemimpinan, Kapabilitas Dinamis, dan Manajemen Pengetahuan ditunjukkan oleh persamaan regresi: $\mathrm{Y}=1,425+0,625 \mathrm{X} 1+0,031 \mathrm{X} 2$; dengan $\mathrm{Y}=$ Manajemen Pengetahuan, X1 = Kapabilitas Dinamis, dan X2 = Kepemimpinan. Konstanta sebesar 1,425 menyatakan bahwa jika tidak ada Kepemimpinan atau Kapabilitas Dinamis, Manajemen Pengetahuan nilainya 1,425 (nilai maksimum 5). Koefisien regresi X1 sebesar 0,625 menyatakan 
bahwa setiap penambahan (tanda +) 1 skala (dari skala Likert 5) Kapabilitas Dinamis, maka Manajemen Pengetahuan akan meningkat 0,625 skala. Koefisien regresi X2 sebesar 0,031 menyatakan bahwa setiap penambahan (+) 1 skala Kepemimpinan, akan meningkatkan Manajemen sebesar 0,031 skala.

Berdasarkan uji signifikansi independent variable diperoleh hasil bahwa Kapabilitas Dinamis berpengaruh secara signifikan terhadap Manajemen Pengetahuan (angka signfikansi 0,000). Sedangkan variabel Kepemimpinan tidak signifikan pengaruhnya terhadap Manajemen Pengetahuan (signifikansi 0,733). Terakhir, variabel Kepemimpinan memiliki dua fungsi, yaitu sebagai independent variable, tetapi harus dikontrol dan sebagai independent variable kedua atau sebagai mediator.

\section{DAFTAR PUSTAKA}

Ali, H. M. (2006). Knowledge Leadership vs. Knowledge Management. In H. M. Ali, \& i. M. Khosrow-Pour (Ed.), Emeerging Trends and Challenges in Information Technology Management (Vol. 1 \& 2, pp. 1-6). Kedah, Malaysia: Idea Group.

Al-Zegaier, H. (2012). Estimating the impact of leadership styles on knowledge management application strategies. European Journal of Business and Management, 4(21), 88-99.

Bass, B. (1990). From transactional to transformational leadership: Learning to share the vision. Organizational Dynamics, 18(3), 19-31.

Crawford, C. B. (2003). Exploring the relationship between knowledge management and transformational leadership. Knowledge Management and Leadership, 1-13. http://leadershipeducators.org/Resources/Documents/Conferences/Anchorage/crawford.pdf

Easterby-Smith, M. \& Prieto, I. M. (2008). Dynamic capabilities and knowledge management: An integrative role for learning? British Journal of Management, 19(3), 235-249. $\quad$ doi: 10.1111/j.1467-8551.2007.00543.x

Elfindri. (2013, 21 Maret). Membina PTS. Diakses 4 Juni 2013 dari http://edukasi.kompas.com/read/2013/03/21/09471975/Membina.PTS.

Gooderham, P. N. (2007). Enhancing knowledge transfer in multinational corporations: A dynamic capabilities driven. Knowledge Management Research \& Practice, 5, 34-43. doi:10.1057/palgrave.kmrp.8500119

Gold, A.H., Malhotra, A., and Segars, A.H. 2001. Knowledge Management: An Organizational Capabilities Perspective. Journal of Management Information Systems, 18 (1): 185-214.

Hair, J. F. (2010). Multivariate Data Analysis A Global Perspective. Seventh Edition. New Jersey: Pearson Education.

Hamilton, M. (2010). The Interaction of Transactional and Transformational Leadership. Online Journal of Workforce Education and Development, 3(3), 1-11.

Jashapara, A. (2011). Knowledge Management: An Integrated Approach. 2 Ed. New Jersey: Pearson. 
Jiao, H., Alon, I., \& Kwong K. C. (2011). The moderating effects of environmental dynamism on the relationship between dynamic capabilities strategy and new venture performance in an emerging market. Working Papers, Management Series, 13.

Malhotra, N. (2007). Marketing Research: an Applied Orientation. $5^{\text {th }}$ Ed. New Jearsey, USA: Pearson.

Martin, B. (2000). Knowledge based organizations: emerging trends in local government in Australia. Journal of Knowledge Management Practice. Diakses http://www.tlainc.com/articl16.htm

McKinsey and Company. (2012). The State of Human Capital 2012. Research Report R-1501-12-RR

Nizam. (2013). Enriching Education to Prepare Competitive Global Citizen. Global Leadership Forum.

Nguyen, Q. T. N. \& Neck, P. A. (2008). Knowledge management as dynamic capabilities: Does it work in emerging less developed contries? Proceedings of The 16th Annual Conference on Pacific Basin Finance, Economics, Accounting and Management, 1-18. Australia: Queensland University of Technology (QUT).

1

Nguyen, Q. T. N., Neck, P. A., \& Nguyen, T. H. (2009). The critical role of knowledge management in achieving and sustaining organizational competitive advantage. International Business Research, 2(3), 3-16.

Putong, I. (2007). Economics, Pengantar Ekonomi Mikro Makro. Edisi 4. Jakarta: Mitra Wacana Media.

Riduwan \& Kuncoro, E. A. (2007). Cara Menggunakan dan Memakai Analisis Jalur (Path Analysis). Bandung: Alfabeta.

Ryan, S. D., Zhang, X., Prybutok, V. R., \& Sharp, J. H. (2012). Leadership and knowledge management in an e-government environment. Adminstrative Science, 2(1), 63-81. doi:10.3390/admsci2010063\#sthash.N175qmbP.dpuf

Sekaran, U. \& Bougie, R. (2010). Research Method for Business. A Skill Building Approach. UK: John Wiley and Sons.

Suharti, L., \& Hartanto, I. (2009). Identifikasi kesiapan penerapan knowledge management di perguruan tinggi (studi terhadap faktor pemberdayaan (enablers) knowledge management). Jurnal Ekonomi dan Bisnis, 15(2), 181-196.

Sugiyono. (2010). Metode penelitian Kuantitatif Kualitatif dan R\&D, Bandung: Alfabeta.

Supranto, J. (2007). Teknik Sampling untuk Survey dan Eksperimen. Jakarta: Rineka Cipta.

Teece, D. J., Pisano, G., Shuen, A. (1997). Dynamic Capabilities and Strategic Management. Strategic Management Journal, 18(7), 509-533.

Uit Beijerse, R. P. (2000). Knowledge management in small and medium-sized companies: knowledge management for entrepreneurs. Journal of Knowledge Management, 4(2), 162-179. 